\title{
PENGARUH PELAPISAN XANTOFIL PADA SEL SURYA SILIKON TERHADAP PENINGKATAN TEGANGAN DAN ARUS LISTRIK
}

\author{
Rubianto A. Lubis, Atiek Rostika Noviyanti, Yudha Prawira Budiman, Reinanda Hanapratiwi, Iman \\ Rahayu \\ Departemen Kimia Fakultas Matematika dan Ilmu Pengetahuan Alam Universitas Padjadjaran \\ Jl. Raya Bandung-Sumedang Km. 21 Jatinangor, Sumedang Indonesia, 46353 \\ *Alamat Korespondensi: antolubis52@gmail.com
}

\begin{abstract}
Abstrak: Sifat semikonduktor yang dimiliki silikon memungkinkan terjadinya aliran listrik melalui suatu sambungan P-N. Salah satu modifikasi untuk meningkatkan tegangan serta arus listrik pada sel surya adalah dengan menambahkan suatu zat warna seperti xantofil pada permukaannya. Penelitian ini bertujuan untuk mengetahui pengaruh pelapisan xantolfil dengan konsentrasi (10\%, 20\% dan 30\%) pada sel surya terhadap tegangan listrik serta arus listrik yang dihasilkan. Metode preparasi sel surya adalah metode difusi yaitu menempelkan padatan fosfor secara langsung pada silikon tipe-P pada suhu $900^{\circ} \mathrm{C}$. Peningkatan arus dan tegangan listrik pada permukaan sel surya yang dilapisi xantofil diukur menggunakan avometer. Dari hasil penelitian didapatkan kenaikan tegangan listrik maksimum sebesar 2,38\% dan kenaikan arus listrik maksimum sebesar $7,53 \%$.
\end{abstract}

Kata kunci: sel surya, semikonduktor, silikon, difusi, xantofil

Abstract: Semiconductor of silicon allows the flow of electricity through a $P$ - $N$ junction. One modification that can increase the voltage and electric current in solar cells is by adding dye onto the surface of solar cells such as xantophyll. This study aims to determine the effect xanthophyll coating on solar cells to electric voltage and electric current. Preparation of solar sel carried out by directly diffusing of phosphorus to the P-type silicon at $900^{\circ} \mathrm{C}$. Current and voltage of electricity generated from solar cells was measured by using an avometer. The maximum increases in voltage and electric current were $2.38 \%$ and $7.53 \%$ respectively.

Keywords: solar cell, semiconductor, silicon, diffusion, xanthophyll

\section{PENDAHULUAN}

Saat ini kebutuhan energi semakin meningkat, namun cadangan bahan bakar yang bersumber dari fosil makin lama makin berkurang. Energi alternatif, khususnya energi yang tidak habis pakai, sangat dibutuhkan untuk mengurangi konsumsi bahan bakar fosil. Salah satu alternatif sumber energi adalah memanfaatkan matahari sebagai sumbernya. Sel surya berfungsi untuk mengkonversi energi surya menjadi energi listrik, alat ini mulai dikembangkan pada abad ke-20 akibat adanya krisis minyak bumi (Dobranzski et al. 2012).

Secara geografis Indonesia terletak disekitar garis khatulistiwa dan beriklim tropis, sehingga sinar matahari (surya) diterima hampir sepanjang hari. Penggunaan sel surya sebagai energi alternatif memiliki beberapa keuntungan karena cahaya matahari yang tidak terbatas, bebas polusi serta proses pengerjaan yang relatif sederhana.

Mengacu pada azas fotovoltaik, sel surya umumnya dibuat dari material dasar kristal silikon karena keberadaanya yang melimpah, sifatnya yang non toksik serta efisiensi konversi yang dihasilkan tinggi (Blakers et al. 2013). Transformasi energi surya menjadi energi listrik memanfaatkan kristal semikonduktor yang memiliki tipe-P di satu sisi dan tipe-N di sisi lainnya dengan daerah pembatas yang disebut sambungan P-N. Untuk mentransformasikan energi surya menjadi energi listrik, jenis silikon tipe$\mathrm{N}$ harus selalu berpasangan dengan silikon tipe-P.

Metode umum yang digunakan untuk menghasilan sambungan $\mathrm{P}-\mathrm{N}$ adalah proses difusi padatan (Ghembaza et al. 2014), dalam hal ini fosfor digunakan untuk membuat sambungan P-N dari silikon tipe-P. Hasil keluaran (output) potensial listrik serta arus listrik yang optimum bergantung pada kemampuan sel surya untuk menyerap cahaya.

Penggunaan sel surya telah banyak dimanfaatkan dengan baik di Indonesia, namun kinerja sel surya masih perlu ditingkatkan. Penambahan zat warna seperti zat warna hijau daun pada permukaan sel surya dapat menambah kemampuan sel surya untuk mengkonversi energi matahari menjadi energi listrik (Amadi et al. 2015). Penambahan lapisan xantofil (salah satu zat hijau daun) pada permukaan sel surya untuk mengetahui pengaruhnya terhadap kenaikan tegangan serta arus listrik yang dihasilkan. Pelapisan zat warna pada sel surya memerlukan suatu media perekat transparan (Amadi et al. 2015). Lapisan di atas permukaan sel surya harus bersifat transparan agar cahaya dapat diserap oleh sel surya (Amadi et al. 2015). Pada penelitian ini dipilih gelatin dan amilum sebagai media perekat lapisan xantofil pada permukaan sel surya.

Berdasarkan latar belakang di atas, maka penelitian ini dilakukan untuk mengetahui pengaruh penambahan lapisan xantofil dengan menggunakan 
perekat gelatin dan amilum. Konsentrasi lapisan xantofil pada sel surya mempengaruhi kenaikan tegangan dan arus listrik yang dihasilkan. Konsentrasi xantofil sebanyak 10\%, 20\% dan 30\% dibuat untuk mengevalusi pengaruh konsentrasi zat warna sebagai pelapis pada sel surya terhadap kenaikan arus dan tegangan listrik yang dihasilkan.

\section{BAHAN DAN METODE}

Penelitian ini menggunakan bahan kristal silikon tipe-P sebagai bahan pembuatan wafer sel surya yang telah di doping menggunakan unsur golongan 13, yaitu boron.

Prosedur penelitian yang dilakukan pada penelitian ini meliputi beberapa tahapan proses sebagai berikut: proses oksidasi, proses pengikisan lapisan oksida (etching), proses difusi, proses penstabilan (drive in), pemisahan pigmen xantofil dari pigmen plastid, penambahan lapisan xantofil pada wafer sel surya serta pengukuran tegangan listrik dan arus listrik.

\section{Pra Oksidasi}

Silikon tipe-P terlebih dahulu dicuci menggunakan aseton dan larutan hidrogen fluorida. Setelah itu, pencucian dilanjutkan menggunakan campuran larutan asam sulfat dan hidrogen peroksida. Pencucian ini bertujuan untuk menghilangkan zat organik serta lemak yang menempel pada silikon tipe-P. Asam sulfat dan hidrogen peroksida merupakan asam anorganik bersifat oksidator kuat yang akan mengoksidasi zatzat organik.

\section{Proses Oksidasi dan difusi}

Pada tahap awal, silikon tipe-P (wafer) dicuci dengan aseton, kemudian didinginkan lalu dicelupkan pada larutan hidrogen fluorida $20 \%$ selama 15 detik. Wafer kemudian dibilas dengan air suling dan pencucian dilanjutkan dengan larutan campuran asam sulfat dan hidrogen peroksida dengan perbandingan 4:1. Wafer yang sudah dipreparasi direndam 15 detik, selanjutnya dibilas dengan air suling.

Wafer silikon tipe-N yang telah bersih dari pengotor selanjutnya dioksidasi menggunakan gas oksigen sambil dengan pemanasan pada suhu $900^{\circ} \mathrm{C}$ selama 1 jam. Salah satu permukaan wafer ditutup dengan menggunakan lilin, kemudian dilakukan eitching oleh hidrogen fluorida $20 \%$ selama 15 menit, selanjutnya dicuci dengan akuades. Wafer dan padatan fosfor dimasukkan dalam tanur dengan posisi sejajar dan hampir menempel kemudian dibakar pada suhu $900^{\circ} \mathrm{C}$ selama 25 menit.

\section{Proses Penstabilan (Drive In)}

Proses ini dilakukan dengan cara mencuci dengan aseton, kemudian dibilas dengan akuades, dan dicuci dengan larutan campuran asam sulfat pekat dan hidrogen peroksida dengan perbandingan $4: 1$. Wafer kemudian dipanaskan selama 5 menit lalu didinginkan, setelah dingin wafer dibilas kembali dengan air dan dikeringkan dengan gas nitrogen.
Setelah proses penstabilan selesai, wafer dimasukkan kedalam tanur dan dipanaskan secara bertahap sampai suhu mencapai $900^{\circ} \mathrm{C}$ selama 90 menit sambil dialiri gas oksigen.

\section{Ekstraksi Xantofil}

Xantofil diperoleh dengan cara mengekstraksi daun singkong yang telah dihaluskan dan dikeringkan di dalam oven. Sebanyak $10 \mathrm{~g}$ serbuk daun singkong kering digerus sampai halus sambil ditambahkan 30 $\mathrm{mL}$ aseton. Proses ekstraksi dilanjutkan dengan melarutkan daun singkong halus ke dalam pelarut petroleum benzen dan air dengan perbandingan 1:5. Setelah terlihat ada pemisahan, lapisan bawah dikeluarkan, hingga hanya tersisa lapisan atasnya. Untuk memaksimalkan prosen ekstraksi, proses ini diulang sebanyak 3 kali (Pavia et al. 1999).

Xantofil dipisahkan dari pigmen plastida dengan menggunakan kromatografi kolom menggunakan matriks selulosa sebagai fase diam dan petroleum benzena sebagai fase gerak.

\section{Penambahan Lapisan Xantofil pada sel surya}

Untuk menambah efisiensi potensial listrik sel surya, xantofil dilapiskan pada seluruh permukaan sel surya secara merata. Pelapisan xantofil dibantu dengan media gelatin dan amilum, dengan perbandingan konsentrasi xantofil $10 \%, 20 \%$ dan $30 \%$. Pengaruh pelapisan xantofil terhadap perubahan tegangan arus serta hambatan listrik diukur dengan avometer.

Sumber cahaya yang digunakan adalah lampu LED 15 watt dengan jarak lampu dan wafer silikon sel surya adalah $1 \mathrm{~cm}, 2 \mathrm{~cm}$ dan $10 \mathrm{~cm}$. Variasi jarak lampu terhadap tegangan listrik dilakukan untuk mengetahui perbedaan tegangan listrik yang dihasilkan pada intensitas sinar yang diterima oleh sel surya. Lampu LED digunakan agar intensitas cahaya yang masuk ke dalam wafer sel surya lebih stabil. Daya sebesar 15 watt digunakan agar intensitas cahaya yang dihasilkan maksimum seperti intensitas cahaya matahari pada keadaan cuaca cerah.

\section{HASIL DAN PEMBAHASAN \\ Pembuatan Sel Surya}

Proses oksidasi silikon tipe-P diamati dengan adanyaperubahan warna dari abu-abu menjadi berwarna biru dan memberikan pantulan seperti cermin (Gambar 1). Warna biru pada silikon tipe-P teroksidasi menunjukkan bahwa masker oksida di permukaan silikontelah terbentuk (Basher \& Shorowordi, 2015). Proses oksidasi pada silikon menjadi silikon dioksida $\left(\mathrm{SiO}_{2}\right)$ terjadi hanya di permukaan silikon. Reaksi yang terjadi sebagai berikut:

$$
\mathrm{Si}_{(\mathrm{s})}+\mathrm{O}_{2(\mathrm{~g})} \rightarrow \mathrm{SiO}_{(\mathrm{s})}
$$

Salah satu permukaan wafer sel surya dihilangkan lapisan oksidanya menggunakan larutan hidrogen flourida. Permukaan yang dihilangkan lapisan oksidanya (proses etching), warna permukaannya berubah kembali menjadi abu-abu seperti semula. 


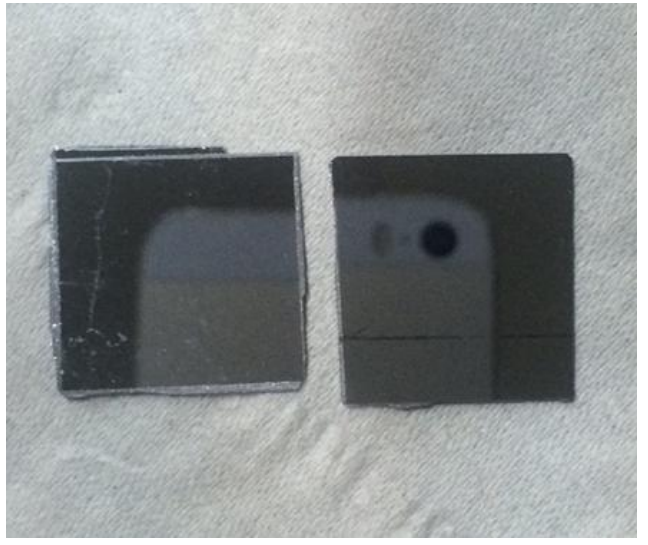

Gambar 1. Permukaan silikon setelah dioksidasi

Proses ini dilakukan agar atom donor pada proses difusi dapat ditambahkan ke dalam kristal silikon tipe-P. Selain itu proses etching juga berfungsi untuk memberikan tekstur pada permukaan silikon, struktur permukaan tersebut dibentuk untuk meningkatkan penyerapan terhadap sinar matahari dan mengurangi pemantulan kembali. Dengan proses tersebut wafer silikon dapat menyerap sinar matahari yang maksimal dan efisiensi dari solar sel dapat ditingkatkan.

Reaksi pada proses etching, silikon dioksida $\left(\mathrm{SiO}_{2}\right)$ bereaksi dengan hidrogen fluorida (HF) membentuk asam fluorosilikat $\left(\mathrm{H}_{2} \mathrm{SiF}_{6}\right)$ sehingga lapisan oksida $\left(\mathrm{SiO}_{2}\right)$ hilang dan permukaan silikon akan terkikis dengan menggunakan asam. Reaksi yang terjadi adalah:

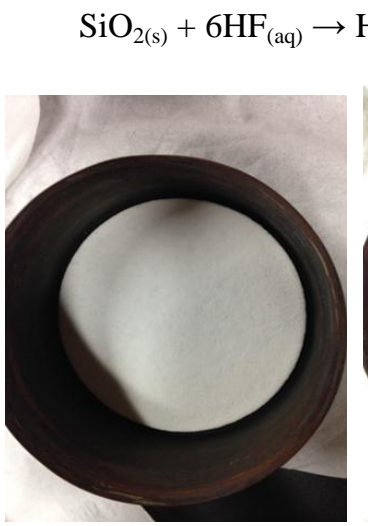

(A)

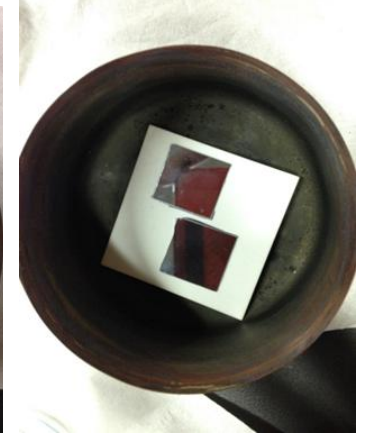

(B)
Gambar 2. (A) Silikon tipe-P sebelum proses difusi. (B) Fosfor tipe-N yang akan didifusikan pada silikon tipe-P.

Pada poses difusi digunakan untuk membentuk silikon tipe-P menjadi silikon dengan sambungan P$\mathrm{N}$ (p-n junction). Proses difusi dilakukan pada suhu $900^{\circ} \mathrm{C}$ selama menggunakan gas nitrogen untuk menghindari terjadinya reaksi dengan silikon tipe-P karena gas nitrogen merupakan gas inert. Suhu yang digunakan $900^{\circ} \mathrm{C}$ untuk mendekati titik leleh silikon yaitu sebesar $1414^{\circ} \mathrm{C}$, agar jarak antar molekul dalam silikon semakin renggang dan fosfor dapat terdifusi dan bereaksi secara sempurna membentuk silikon dengan sambungan P-N (p-n junction). Suhu $900^{\circ} \mathrm{C}$ merupakan suhu minimum yang dapat digunakan untuk mendifusikan fosfor ke dalam silikon tipe-P, seperti yang dilakukan peneliti sebelumnya (Lubis, 1999). Silikon tipe-P sebelum proses difusi dan dan fosfor tipe-N yang akan didifusikan pada silikon tipe$\mathrm{P}$ ditunjukkan pada Gambar 2.

Proses difusi fosfor bertujuan untuk menambahkan suatu atom donor ke dalam inti kristal silikon tipe-P. Difusi fosfor merupakan proses inti dari pembuatan wafer sel surya. Difusi padatan merupakan transfer materi melalui materi lain karena atom atau partikel selalu bergerak oleh gerak termal. Penambahan fosfor ke dalam kristal silikon tipe-P dapat membentuk suatu sambungan antara silikon tipe-P dan silikon tipe-N, yang disebut sambungan PN. Sambungan P-N ini membuat kedua muatan positif (hole) maupun negatif (elektron) dapat berpindah dan mengalir ke arah yang berlawanan. Jika kedua ujung sambungan P-N ini dihubungkan dengan sebuah rangkaianlistrik, maka elektron dan hole dapat mengalir ke rangkaian dan menghasilkan suatu arus listrik.

Proses difusi yang membentuk sambungan P-N meninggalkan daerah yang lebih positif pada batas tipe-N dan daerah lebih negatif pada batas tipe-P. Batas tempat terjadinya perbedaan muatan pada $p-n$ junction disebut dengan daerah deplesi. Adanya perbedaan muatan pada daerah deplesiakan mengakibatkan munculnya medan listrik yang mampu menghentikan laju difusi selanjutnya. Medan listrik tersebut mengakibatkan munculnya arus drift. Namun arus ini terimbangi oleh arus difusi sehingga secara keseluruhan tidak ada arus listrik yang mengalir pada semikonduktor p-n junction (Lubis, 1999). Ketika junction disinari, foton yang mempunyai energi sama atau lebih besar dari lebar pita energi material tersebut akan menyebabkan eksitasi elektron dari pita valensi ke pita konduksi dan akan meninggalkan hole pada pita valensi. Elektron dan hole ini dapat bergerak dalam material sehingga menghasilkan pasangan elektron hole. Apabila ditempatkan hambatan pada terminal sel surya, maka elektron dari area akan kembali ke areap sehingga menyebabkan perbedaan potensial dan arus akan mengalir (Lubis, 1999).

Proses penstabilan (penggunaan masker oksida) dilakukan menggunakan gas oksigen setelah proses difusi untuk melindungi seluruh permukaan wafer silikon.

\section{Pemisahan Xantofil}

Xantofil diperoleh dengan mengekstrak pigmen plastida dari daun singkong yang dilarutkan dalam aseton (Pavia et al. 1999). Ekstrak pigmen plastida dilanjutkan dengan proses ekstraksi kembali oleh pelarut petroleum benzena dan akuades yang bertujuan untuk mengekstrak pigmen plastida bebas 


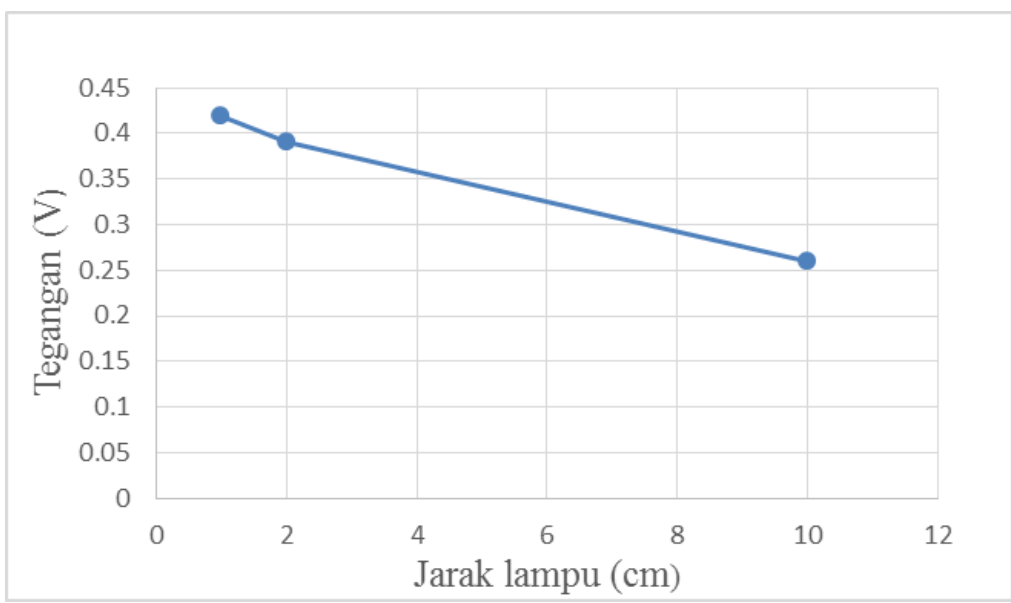

Gambar 3. Grafik pengaruh jarak lampu LED 15 watt - wafer silikon sel surya terhadap nilai tegangan awal yang dihasilkan.

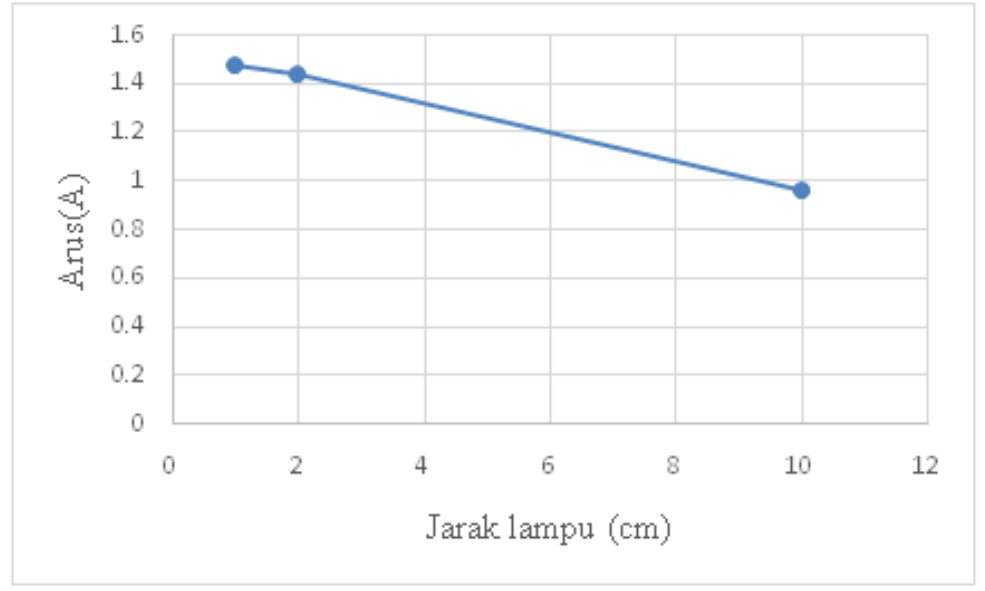

Gambar 4. Grafik pengaruh jarak lampu LED 15 watt - wafer silikon sel surya terhadap nilai arus listrikyang dihasilkan

aseton. Petroleum benzena berfungsi untuk mengikat pigmen plastida, sedangkan akuades berfungsi untuk mengikat aseton. Pemisahan ini didasarkan atas perbedaan kepolaran antara pigmen plastida dan aseton (Pavia et al. 1999). Aseton harus dihilangkan untuk mempermudah pemisahan pigmen plastida menggunakan kromatografi kolom yang didasarkan pada perbedaan kepolaran.

Selulosa dipilih sebagai fase diam dalam pemisahan pigmen plastida karena selulosa bersifat polar dan memiliki gugus hidroksil yang dapat berikatan dengan gugus hidroksil lain pada klorofil (Pavia et al. 1999).

Setelah ekstrak pigmen plastida dimasukkan ke dalam kolom, maka terjadi proses adsorpsi komponen-komponen pigmen oleh matriks selulosa akibat dari perbedaan kepolaran. Pigmen-pigmen plastida pada kolom terpisah berdasarkan warnanya, pigmen xantofil berwarna kuning kehijauan. Perbedaan warna ini disebabkan oleh perbedaan gugus kromofor yang terkandung dalam senyawa tersebut (Niyogi et al. 1997). Perbedaan gugus kromofor menyebabkan masing-masing pigmen plastida menyerap pada panjang gelombang tertentu. Selulosa dapat menahan klorofil agar tidak turun sebagai eluat, sehingga $\beta$-karoten dan xantofil dapat turun dan terpisah sebagai eluat. Xantofil turun sebagai eluat setelah $\beta$-karoten, karena pada salah satu ujungnya terdapat gugus oksigen yang dapat menambah kepolarannya, sehingga tertahan lebih lama pada selulosa dibandingkan dengan $\beta$-karoten.

\section{Pengukuran Tegangan dan Arus Listrik}

Pengukuran tegangan listrik dan arus listrik pada wafer silikon sel surya dilakukan sebelum dan sesudah pelapisan oleh xantofil menggunakan avometer. Grafik antara tegangan dan arus terhadap jarak lampu masing-masing ditunjukkan pada Gambar 3 dan Gambar 4.

Berdasarkan Gambar 3 terlihat bahwa semakin dekat jarak lampu dengan wafer silikon sel surya maka tegangan listrik yang dihasilkan semakin besar karena semakin banyak sinar yang diterima dan 


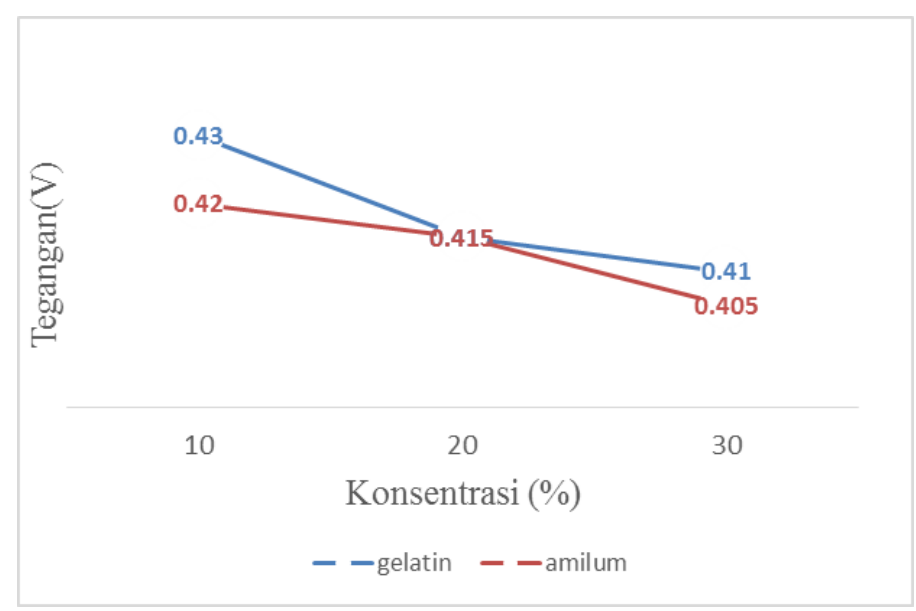

Gambar 5. Kurva pengaruh berbedaan konsentrasi xantofil dalam media gelatian dan amilum terhadap nilai tegangan akhir yang dihasilkan.

Tabel 1. Kenaikan Tegangan Listrik dan Arus Listrik

\begin{tabular}{ccccc}
\hline Konsentrasi / & \multicolumn{2}{c}{ Kenaikan tegangan / $\%$} & \multicolumn{2}{c}{ Kenaikan arus / \% } \\
\cline { 2 - 5 }$\%$ & Gelatin & Amilum & Gelatin & Amilum \\
\hline 10 & 2,38 & 0 & 7,53 & 5,02 \\
20 & $-1,19$ & $-1,19$ & 3,79 & 3,79 \\
30 & $-2,38$ & $-3,57$ & 2,51 & 1,29
\end{tabular}

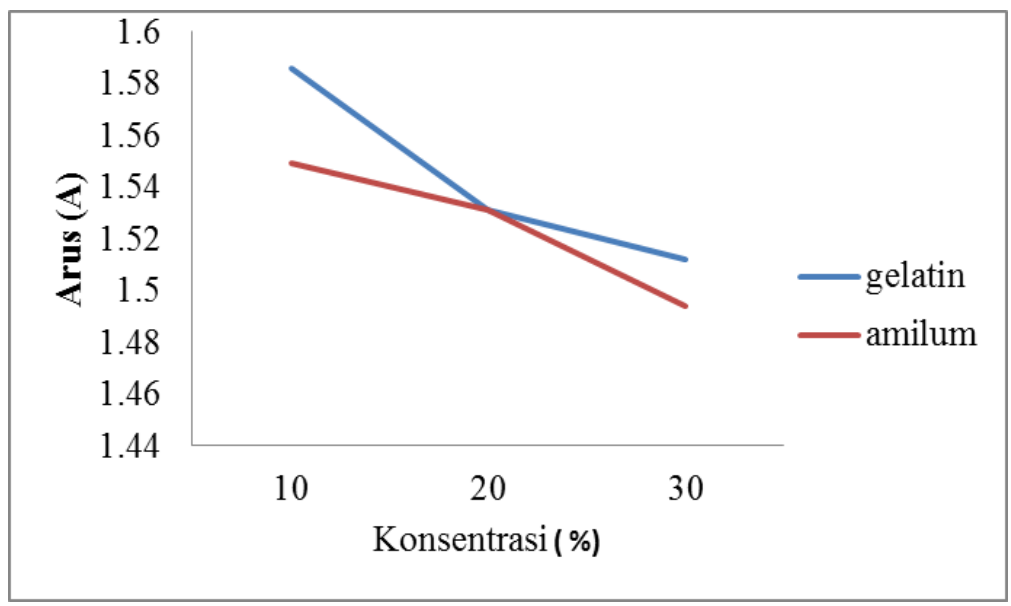

Gambar 6. Kurva pengaruh konsentrasi media gelatin dan amilum terhadap nilai arus listrik akhir.

diserap oleh wafer silikon, sehingga tegangan yang didapat menjadi lebih besar.

Berdasarkan Gambar 4 arus listrik yang mengalir turun seiring meningkatnya jarak lampu dengan wafer sel surya, hal ini disebabkan berkurangnya intensitas sinar yang diserap oleh wafer sel surya.

Untuk mengetahui pengaruh konsentrasi xantofil terhadap peningkatan tegangan listrik wafer sel surya, konsentrasi $10 \%$, 20\% dan 30\% dipilih sebagai variasinya (Gambar 5).
Semakin besar konsentrasi xantofil yang ditambahkan, semakin menurun nilai tegangannya. Hal ini dikarenakan semakin besar konsentrasi xantofil, semakin tebal juga lapisan yang menutupi permukaan wafer silikon sehingga sinar lebih sulit untuk diserap oleh wafer silikon.

Selain pengaruh konsentrasi xantofilnya juga diteliti pengaruh media pelapisan xantofil pada permukaan sel surya.Media yang digunakan adalah amilum dan gelatin. Konsentrasi gelatin $10 \%$ 
merupakan media terbaik untuk meningkatkan tegangan listrik sel surya.

Pengaruh pelapisan xantofil dengan media amilum dan gelatin terhadap arus listrik pada sel surya yang telah ditunjukkan pada Gambar 6 dan Tabel 1.

Arus listrik maksimum diperoleh dengan menggunakan xantofil dengan konsentrasi $10 \%$ dalam media gelatin yaitu sebesar 1,586 A, sedangkan pada media amilum 1,549 A. Perbedan nilai arus lisrik pada media gelatin dan amilum tidak jauh berbeda, namun menggunakan media gelatin menghasilkan arus listrik yang sedikit lebih tinggi. Hal ini diduga cahaya yang diterima oleh sel surya lebih banyak dengan media gelatin karena lebih transparan dibandingkan amilum. Suatu sel surya dapat menerima cahaya secara maksimum jika lapisan yang ditambahkan di atas permukaan sel surya bersifat sangat transparan.

Menurut Niyogi et al. (1997), xantofil merupakan pigmen kuning grup karotenoid pada daun yang memiliki panjang gelombang $410 \mathrm{~nm}$, xantofil dapat tereksitasi dengan adanya penyinaran pada pelapisan wafer sel surya. Pewarna yang digunakan memiliki gugus kromofor yang terkonjugasi sehingga memungkinkan terjadi transfer elektron dan mampu menaikan tegangan listrik dari wafer silikon. Pewarna tersebut memegang peranan penting dalam proses absorpsi foton. Foton yang diserap molekul pewarna akan mengeksitasi elektron, semakin banyak foton yang dapat dieksitasi untuk dikonversikan oleh sel surya menjadi energi listrik.

Penambahan lapisan xantofil 10\% dengan media gelatin menghasilkan kenaikan tegangan listrik yang paling tinggi dibandingkan penambahan lapisan xantofil $20 \%$ dan $30 \%$. Berbeda dengan perubahan nilai tegangan penambahan xantofil pada konsentrasi $10 \%, 20 \%$ dan $30 \%$ memberikan kenaikan arus yang dihasilkan.

Peningkatan tegangan maupun arus yang dihasilkan pada pelapisan media amilum tidak lebih baik dari peningkatan efisiensi oleh media gelatin, hal ini disebabkan tertutupnya permukaan wafer sel surya oleh media amilum. Pelapisan dengan media amilum menunjukkan nilai tegangan dan arus yang lebih kecil dari pada menggunakan gelatin karena amilum mempunyai gugus amilosa dan amilopektin (untuk membantu merekatkan xantofil pada permukaan) yang dapat menghalangi intensitas cahaya yang diserap oleh wafer silikon. Sama seperti dengan penggunaan gelatin, semakin besar konsentrasi xantofil yang ditambahkan, semakin menurun nilai tegangan dan arusnya. Hal ini juga dikarenakan karena besarnya konsetrasi yang ditambahkan, mempengaruhi ketebalan lapisan pada permukaan wafer sel surya yang membuat sinar lebih sulit untuk diserap. Tertutupnya permukaan wafer sel surya oleh amilum menyebabkan wafer sel surya kurang dapat menyerap cahaya yang berasal dari lampu LED. Wafer sel surya dapat menyerap cahaya dari lampu LED jika pelapisan yang ditambahkan bersifat transparan, sedangkan media amilum sedikit keruh.

\section{KESIMPULAN}

Penambahan lapisan xantofil $10 \%$ pada wafer sel surya dapat menambah kerja yang dihasilkan oleh sel surya, hal ini dibuktikan dengan meningkatnya tegangan listrik sebesar 2,38\% dengan media gelatin. Begitupula arus listrik meningkat pada seluruh variasi konsentrasi xantofil baik dengan media gelatin maupun amilum, peningkatan arus listrik paling tinggi yaitu sebesar $7,53 \%$ pada pelapisan xantofil $10 \%$ dengan media gelatin.

\section{DAFTAR PUSTAKA}

Amadi, L., Jenny, S.S., Ahmed, A., Brown, N., Yadav, S., Brown, D., Ghann, W., Gayrama, A., Jiru, M. \& Uddin, J. (2015). Creation of natural dye sensitized solar cell by using nanostructured titanium oxide. Nanoscience and Nanoengineering. 3(3): 25-32.

Basher, M.K. \& Shorowordi, K.M. (2015). Fabrication of Monocrystalline Silicon Solar Cell Using Phosphorus Diffusion Technique. International Journal of Scientific and Research Publication. 5(3): 1-7.

Blakers, A., Zin, N., McIntosh, K.R. \& Fong, K. (2013). High Efficiency Silikon Solar Cell. Energy Procedia. 33: 1-10.

Dobranzski, L.A., Drygala, A., Giedroc, M. \& Macek, M. (2012). Monocrystalline Silicon Solar Cells Applied in photovoltaic system. Journal of Achievements in Materials and Manufacturing Engineering. 53(1): 7-13.

Ghembaza, H., Zerga, A. \& Saim, R. (2014). Efficiency improvement of crystalline silicon solar cells by optimizing the doping profile of $\mathrm{POCl}_{3}$ diffusion. International Journal of Scientific \& Technology Research. 3(1): 1-5.

Lubis, R.A. 1999. Difusi Padatan Pada Pembuatan Sel Surya Dalam Kondisi Laboratorium. Karya Ilmiah. Bandung: Universitas Padjadjaran.

Niyogi, K.K., Bjorkman, O. \& Grossman, A.R. (1997). The roles of spesific xanthophylls in photoprotection. Proceedings of the National Academy of Sciences. 94(25): 14162-14167.

Pavia, D.L., Lampman, D.L., Kriz, G.S. \& Engel, R.G. (1999). Introduction to Organic Laboratory Techniques. New York: Saunders College Publishing. 